\title{
Traditional Cultural Heritage vs. Film Sceneries: Evaluating the Degree of Sustainability of Cultural Landscapes
}

\author{
Esther San Sebastián Poch ${ }^{*}$, Urtzi Llano Castresana ${ }^{2}$, Ander de la Fuente Arana ${ }^{1}$ \\ ${ }^{1}$ Department of Architecture in San Sebastian, University of the Basque Country (U.P.V.), San Sebastian 20018, Spain \\ ${ }^{2}$ Department of Engineering in Bilbao, University of the Basque Country (U.P.V.), Bilbao 48013, Spain
}

Corresponding Author Email: esthersansebastianpoch@gmail.com

https://doi.org/10.18280/ijdne.150502

Received: 8 February 2020

Accepted:16 September 2020

\section{Keywords:}

cultural heritage, cultural landscape, film sceneries, film tourism, indicators of sustainable development, degree of conciliation

\begin{abstract}
Cultural tourism is a good way to promote and, consequently, safeguard the cultural heritage of sites. Film tourism is an increasingly demanded form of cultural tourism more focused on the fictional rather than on the authenticity of sites, depriving them from their true identity. This article is proposing a system of indicators of sustainable development in order to evaluate and guarantee long-term sustainability in those sites identified with traditional cultural heritage and where films have been shot. The Historic Centre of Peñíscola, which was declared a Historic-Artistic Site in 1972 and has become film scenery in numerous occasions, has been chosen to be evaluated. The union of a series of film sceneries obtained from the cinema productions that best match the local heritage, through the latter has resulted in a final cultural landscape where the degree of conciliation between them is high. Therefore, the welfare of the host society is in balance with the tourist demands, which makes the Historic Centre of Peñíscola an accurate study case that can contribute to improve a methodology we aim to extrapolate to other tourist destinations threatened by a new uncontrolled mass of tourist.
\end{abstract}

\section{INTRODUCTION}

Cultural tourism is defined as "... that form of tourism whose object is, among other aims, the discovery of monuments and sites..." [1] and, consequently, the discovery of their cultural identity [2]. An increasingly greater demand of this form of tourism since the $1950 \mathrm{~s}$ is contributing to the valuation, the promotion and, as a result, the preservation of the traditional cultural heritage [3]. However, the tourism industry is constantly evolving and so it does the profile of the tourist, who carries more tourism experiences and, consequently, demands new and more specific tourist products [4]. These new products are gradually breaking up with the traditional and individual character of the sites and little by little, are focusing on some sort of globally spread example of the folk culture such us food (gastronomy), sports or cinema [5]. In the following article, we will turn our gaze to the latter and more specifically, we will delve into film sceneries and their effects on the traditional cultural heritage.

Film sceneries are those sites chosen for the shooting of cinema productions. Film tourism is that form of cultural tourism which encourages tourist to visit film sceneries [6]. A rocketing increase in film tourism demand involves the arrival of new masses of tourists and, consequently, the promotion of tourist destinations and their local heritage.

But, as we have said before, people are steadily drawing their attention to those fictional sceneries drawn out from movies by the time they are pulling away from their true identity and their monuments' [7]. The shooting of internationally known film franchises such as "Harry Potter" [8], "The Lord of the Rings" [9] or the most recent "Game of Thrones"[10] is resulting in a considerable increase of the annual number of tourists who are more willing to walk through the streets of King's Landing ( "Game of thrones" [10]) rather than through the streets of the Old City of Dubrovnik (Figure 1), declared a World Heritage Site in 1979 or to travel on board of the Hogwarts Express ("Harry Potter" [8]) rather than on the Jacobite Steam Train throughout Scottish landscapes. A lack of control of the current situation can relegate traditional cultural heritage to a second place, being led into reification and, as a consequence, host communities could lose their identity and their singularity in favor of a globally shared policy.

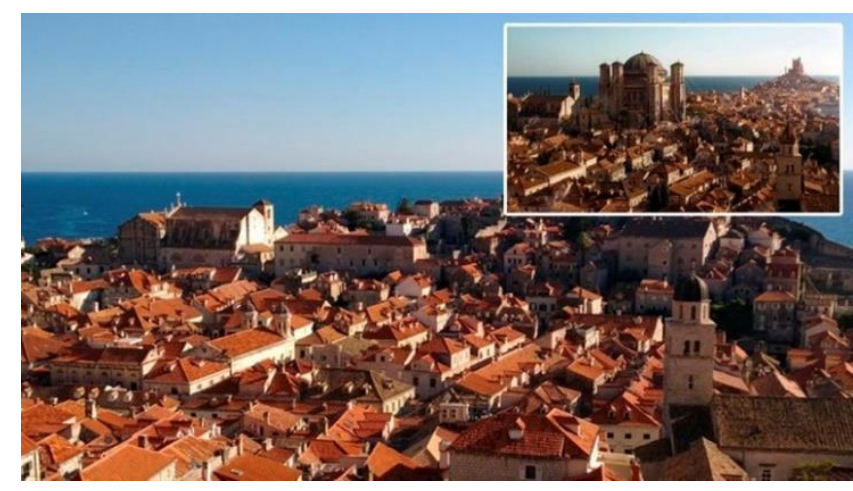

Figure 1. A view of the Old City of Dubrovnik and its transformation into King's Landing for the TV series "Game of Thrones" (2011-2019)

Furthermore, this dizzying and constant growth of tourist demands is threatening the traditional lifestyles of the host communities for two reasons: either because they may not be 
prepared for a new mass of tourists or because the locations themselves live of tourism and they are the ones who make those changes in favor of tourist demands, giving up their true identity. In the first case, we can name some coastal towns of the Basque Country such as Zumaia and Bermeo which already possess their own cultural and landscape heritage, but the shooting of the previously mentioned TV series "Game of Thrones" [10] has put them on the mainstream moviemaking map. In the second case, we have the tourist city of San Sebastian (Basque Country), whose appointment as European Capital of Culture in 2016 and the upcoming premiere of director Woody Allen's last movie, "Rifkin's Festival" [11] (Figure 2), are transforming it into some kind of theme park.

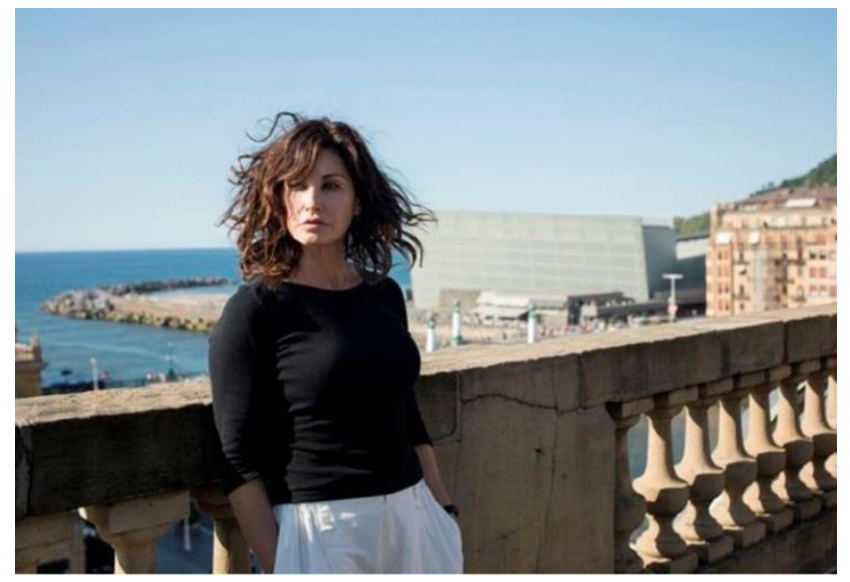

Figure 2. A scene from the film "Rifkin's Festival" (2020), shot in San Sebastian, at the Hotel María Cristina (1912) and with views over architect Rafael Moneo's Kursaal

Auditorium (1999)

All these reasons justify a global concern about the current and future (non)-sustainability of the tourist destinations and, as a consequence, an increased interest for defining systems of indicators that can contribute to evaluate and guarantee longterm sustainability in those sites. In this article, we are proposing a system of indicators of sustainable development focused on those places originally characterized by a traditional cultural heritage, but worldwide famous for having become a film scenery for various cinema productions that have shocked the global society.

A model of sustainability seeks for the right balance between the stability and welfare of host societies and tourist demands. This requires a profound respect for the former's socio-cultural authenticity; a good use of their environmental resources and the creation of a series of activities that can bring long term economic benefits to their agents [12].

According to the UNWTO and as it has been reported in its book "Indicators of Sustainable Development for Tourist Destinations", systems of indicators basically consist of two phases: firstly, a selection of indicators derived from identifying tourist destinations, their attractions and, consequently, the harm uncontrolled tourism may cause to them; secondly, their evaluation [13].

However, an initial selection of indicators may lead us to multiple, varied possibilities, (non) measurable, which need to be reduced and consecutively evaluated according to a single unit of measurement. To do this, we will resort to "Synthetic Indicators", which help us reduce the number of indicators, keeping the volume of information, quantifying the unquantifiable (the degree of sustainability) and getting rid of part of the subjectivity involved in the study case, the analyst and his election and evaluation criteria [14]. In short, the best way to build a synthetic indicator is up to the analyst and his election of an aggregation process in accordance to what each single study case requires.

\section{A NEW METHODOLOGY, WHAT FOR?}

However, if there are so many systems of indicators, what is the point of a new one? Why not making use of the already existing ones? On the one hand, we need to resort to the latter and make use of an aggregation process because we need reduce the number of indicators and reach three final synthetic indicators, referred to the socio-cultural, environmental and economical concepts, but always keeping their whole content.

On the other hand, we are seeking neither to quantify the unquantifiable, nor to suppress the subjectivity of the questions, indicators and their future evaluation for various reasons. Firstly, there are several factors, especially those related to culture, which are many and diverse, entirely subjective, non-measurable and constantly evolving [15] and as a result, it is not worth to summarizing them in a single accounting unit of measurement. Secondly and finally, getting rid of the subjective character of the indicators involves the suppression of the study cases', leaving aside their singularities and evaluating them according to their similarities and the same parameters. For these reasons, we are proposing a more qualitative system, applied in all those sites whose traditional cultural heritage and lifestyles are being threatened by a new mass of tourist attracted by film sceneries and for which they may not be prepared.

The choice of sites for the shooting of cinema productions involves a connection between these (REALITY) and the film sceneries they are about to become (FICTION). Sites identify themselves with a series of elements (built heritage, landscape heritage...) that compose them, standing out their individual, authentic character and making the difference from the rest. In short, it is their singularities what makes each site more or less accurate for creating the right atmosphere for films or TV series, establishing a link between fiction and reality, ensuring a certain degree of conciliation and, as a result, an accurate balance between them. Sites can become film sceneries many times, resulting in several, unique and unrepeatable study cases.

Although this new methodology aims to focus on all those sites identified with the characteristics we have stated before, in the following article we are looking in-depth into small and medium-sized coastal towns since the beach tourism is a very attractive type of tourism and this means that these sites might be lightly accustomed to tourists. Furthermore, a study of their current degree of sustainability, even before they became film sceneries, would be more than appropriate and interesting to collect data. Alongside this article, we will expose the study case of the Historic Centre of Peñíscola (Community of Valencia, Spain), which was appointed a Historic-Artistic Site in 1972 and has become a film scenery in numerous occasions since the 1920s. Apart from collecting data and reaching a series of conclusions, this study case will help us prove and improve the new methodology. 


\section{A SYSTEM OF INDICATORS OF SUSTAINABLE DEVELOPMENT: FILM SCENERIES AND CULTURAL HERITAGE}

Figure 3 will help us follow and comprehend this new methodology in a better way.

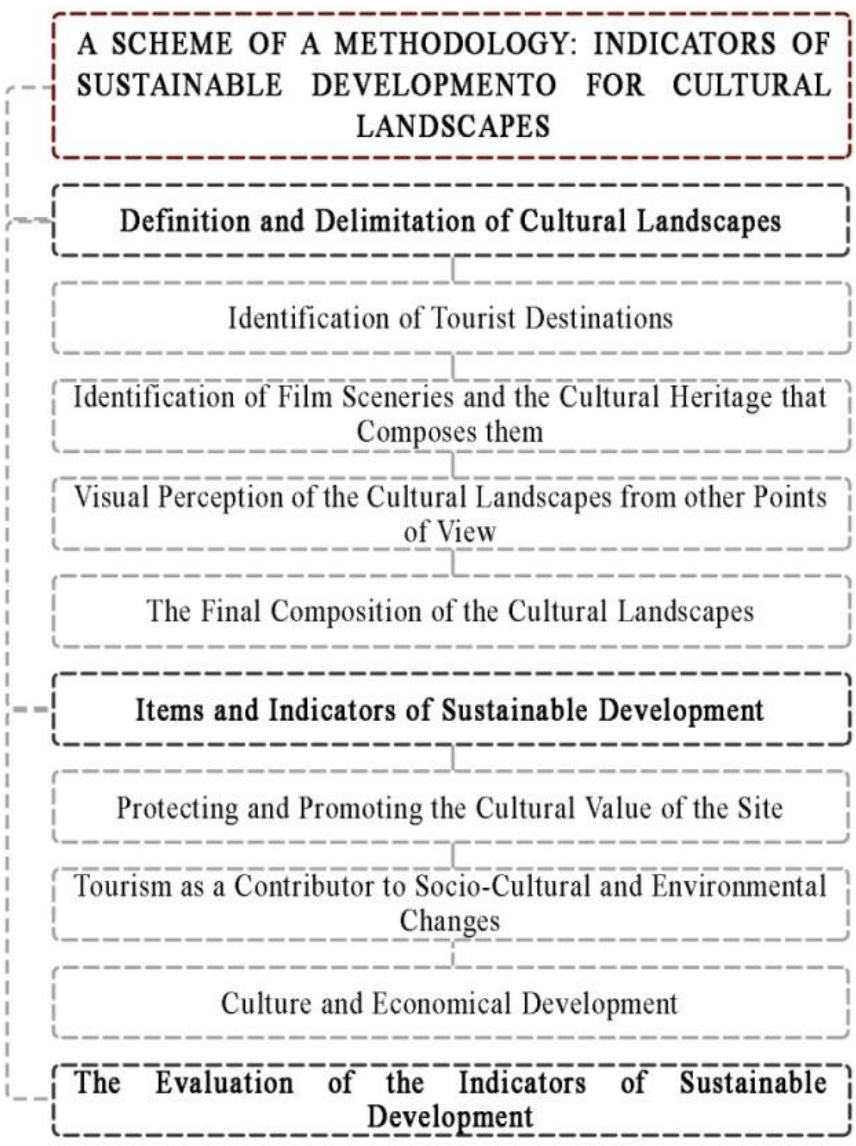

Figure 3. A system of indicators of sustainable development

\subsection{The definition and delimitation of the cultural landscape}

\subsubsection{The definition of the tourist destination}

The first step in this methodology consists of defining the tourist destinations and, to do that, we will resort to the already mentioned book "Indicators of Sustainable Development for Tourism Destinations" and its classifications. According to these, the type of tourist destinations that best fit the study cases we aim to evaluate are: "Built Heritage Sites", "Small and Traditional Communities" and "Urban Tourism" [13] since they are provided with a traditional cultural heritage with whom they identify themselves. However, the inclusion of coastal landscapes and their variety of ecosystems as part of the attractions of tourist destinations we are studying leads us to include the "Coastal Zones", the "Beach Destinations and Sites" and the "Natural and Sensitive Ecological Sites" [13].

3.1.2 Reality vs. Fiction: The identification of the film sceneries and both cultural heritage and stage decorations that compose them

The previous selection of the tourist destinations will lead us to the identification of all the film sceneries and to their decomposition, so that we can identify and differentiate cultural heritage (REALITY) from stage decorations
(FICTION). Firstly, we will start with a compilation of every film, TV series, spot, etc. filmed in the chosen tourist destinations. Later, we will proceed to a final selection valuing both the already mentioned degree of conciliation among the elements that compose the sites (architecture, urbanism, landscapes, etc.) and the film sceneries and both the national and international reception of the public.

After selecting the final cinema productions, we will proceed to recognize all the film scenery. To do that, we must watch carefully the selected filmography, intercept all the film sequences set in the sites to be evaluated and capture every single image/ frame that composes these sequences. Once all the sequences have been identified, we will proceed to a brief description of each of them. This description will include the title of the film or TV series (in the case of the latter, we must include the season and the chapter), the minute of the projection and one or two phrases that describe the sequence and the setting. Finally, all the film sceneries will be collected in one single location plan at different scales, depending on their number, the area they occupy, the level of detail, etc.

Later on, we will analyze the film sceneries separately. Each of them will be represented in another location plan at a larger scale in which we will draw the storylines of the relevant sequences, indicating their continuity or discontinuity. The information given in these plans will be completed with an approximate location and orientation of a few cameras alongside the film routes and referring to some frames (images) directly taken from the film sequences, so that they can keep their length-to width relationship, and chronologically organized for a better comprehension of the latest and the site.

This very same location plan will help us identify the heritage goods and get rid of the stage decorations. The immovable goods are divided into two groups: firstly, the built heritage, which is referred to those buildings and constructions and the immediate surrounding where they stand out or the open urban spaces and the constructions that give shape to them. Secondly, the natural heritage [16]. After having identified all the heritage goods, we will have to collect the most relevant data regarding their heritage value, the state of preservation, the degree of protection and, consequently, the degree of intervention. To do that, we will resort to local codes and guidelines like Built/ Landscape Heritage Protection Plans, Special Reform Plans, etc. Both national and international regulations must be taken into account. But, despite all these regulations, we should always consider appealing to nonwritten information such as local testimonies, photos, etc. which are probably the most precious information since they live in and for their cultural heritage, they are part of it [2].

3.1.3 The visual perception of the cultural landscapes from other points of view

After locating and deconstructing all the film sceneries, we need to get a better perspective, escape from them and perceive them in the distance, from different pedestrian paths. Their perception in the distance will result in a series of items invisible or hardly noticed in films or TV series, but very notable in the landscapes. These are crucial for an accurate definition of the final cultural landscape [17]. That is why they should be clearly indicated in the location plans.

\subsubsection{The final composition of the cultural landscape}

Once we have collected all the film sceneries, identified the heritage good content in them and the items that stand out in the landscape, we will collect them in a final plan where we 
will visualize the final cultural landscape.

3.1.5 A cultural landscape to define: The Historic Centre of Peñíscola

As we have mentioned before, we are going to evaluate the Historic Centre of Peñíscola. This is composed of the Old Town of Peñíscola and the "Influence Area" or its immediate surroundings. The Old Town consists of a residential complex surrounded by Middle-Aged and Renaissance walls, inside which a few buildings such as the Castle of the Pope Luna, the Parochial Church or the Church "La Ermitaña" stand out. The whole complex stands out at the top of a "tombolo" or limestone enclave which was originally linked to the land through a sandy isthmus seriously damaged by the progressive constructions of residential buildings for tourists alongside it. Despite the last fact, the Historic Centre of Peñíscola was declared a Historic-Artistic Site in 1972 (Figure 4).

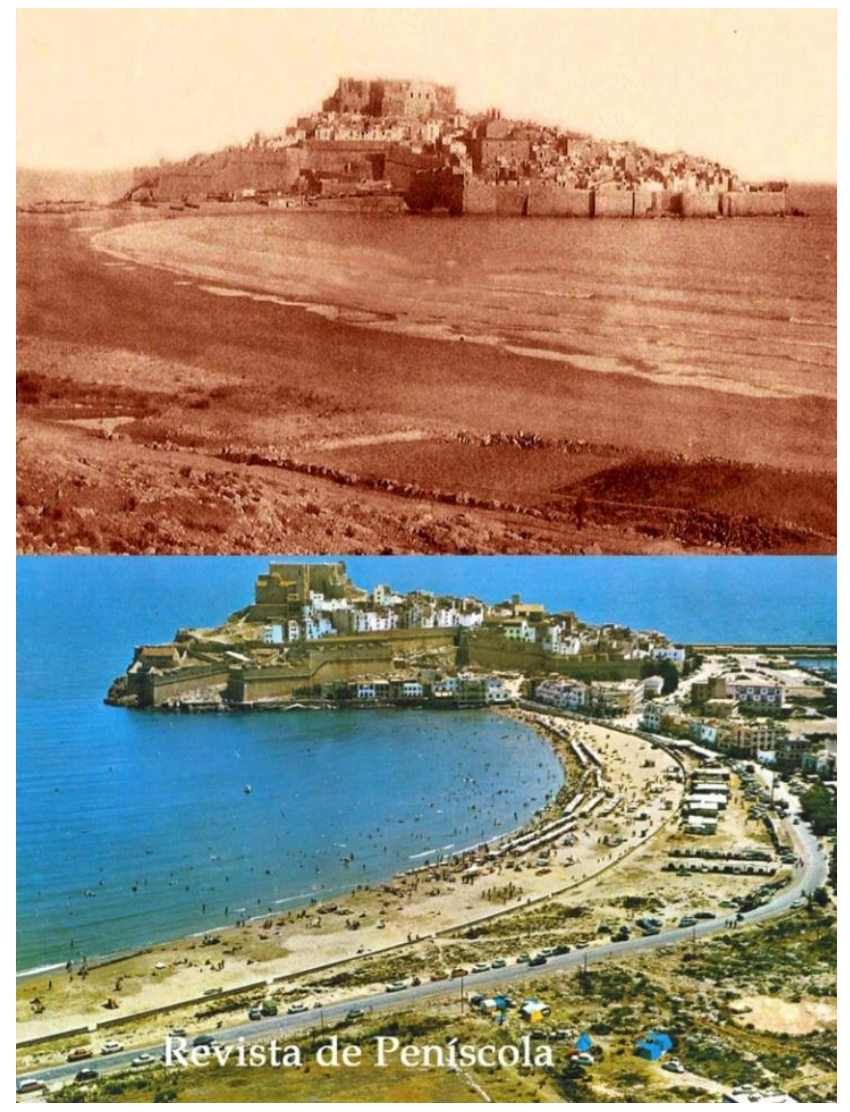

Figure 4. The Historic Centre of Peñíscola (1910s/ 1950s)

On the second hand, this site is also famous for all the cinema and TV productions that have been shot in it since the early $20^{\text {th }}$ century and amongst which we can point out "Calabuch" [18] (Figure 5), "El Cid" [19] (Figure 6), or the already mentioned "Game of thrones" (2011-2019) [10] (Figure 7). For the following study, we are opting for the latest two, as the tall walls of the city were considered accurate for both the recreations of the walled city of Valencia in the $11^{\text {th }}$ century for the movie "El Cid" [19] and the fictional MiddleAged walled city of Meeren in the very popular TV series "Game of Thrones" [10].

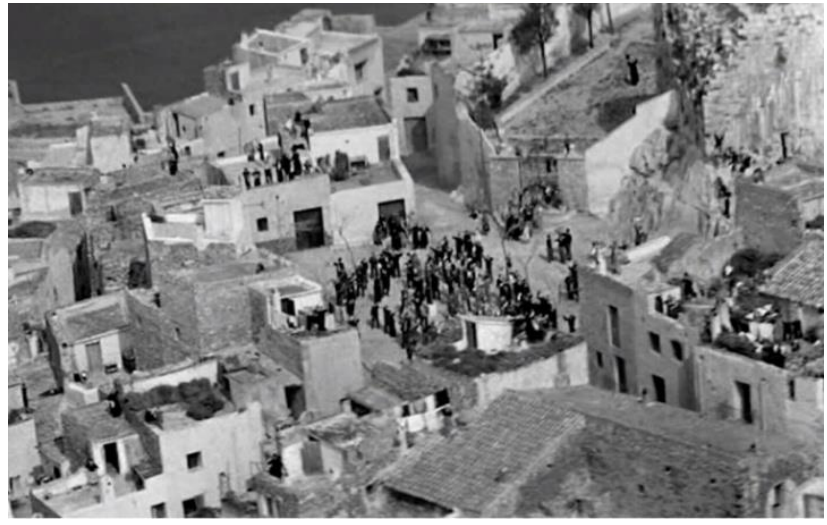

Figure 5. A scene from the film "Calabuch" (1956) shot at the Plaza de Armas, at the top of the historic complex of Peñíscola

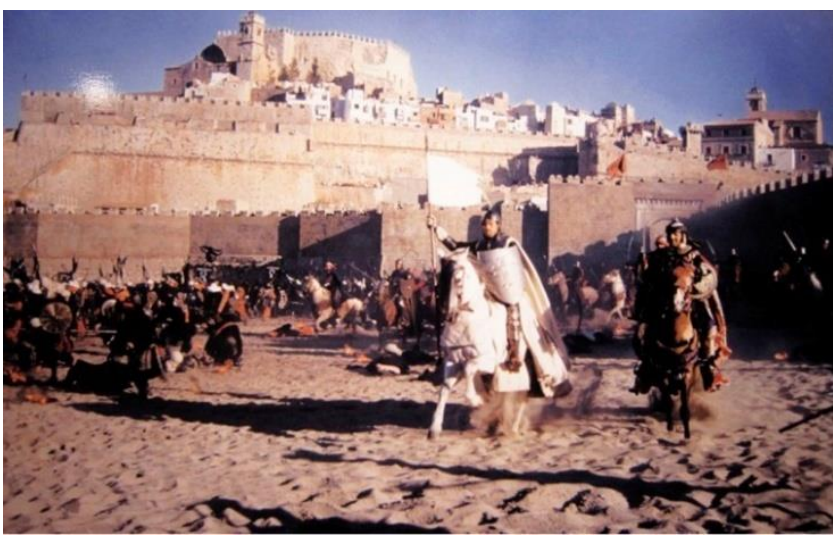

Figure 6. A scene from the film "El Cid" (1961) shot at the Northern Beach and with views over the historic complex and the Castle of Pope Luna at the top of the tombolo

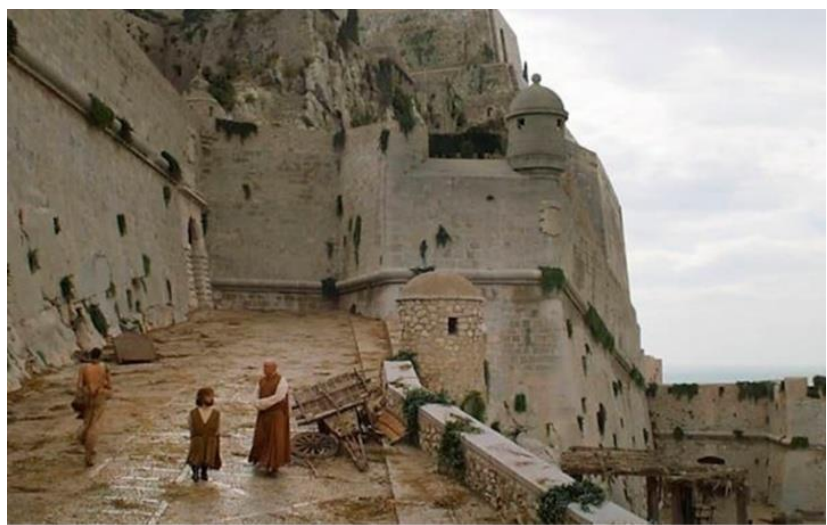

Figure 7. A scene from the TV series "Game of thrones" (2011-2019) shot alongside the Ramp of Felipe II

The sum of both cinema productions equals a total of four film sceneries, clearly indicated in a location plan (Figure 8). These four have been studied separately, identifying all the heritage goods that conform them, getting rid of all the stage decorations (Figure 8) and collecting them in the final plan where we can visualize the final cultural landscape (Figure 9). 


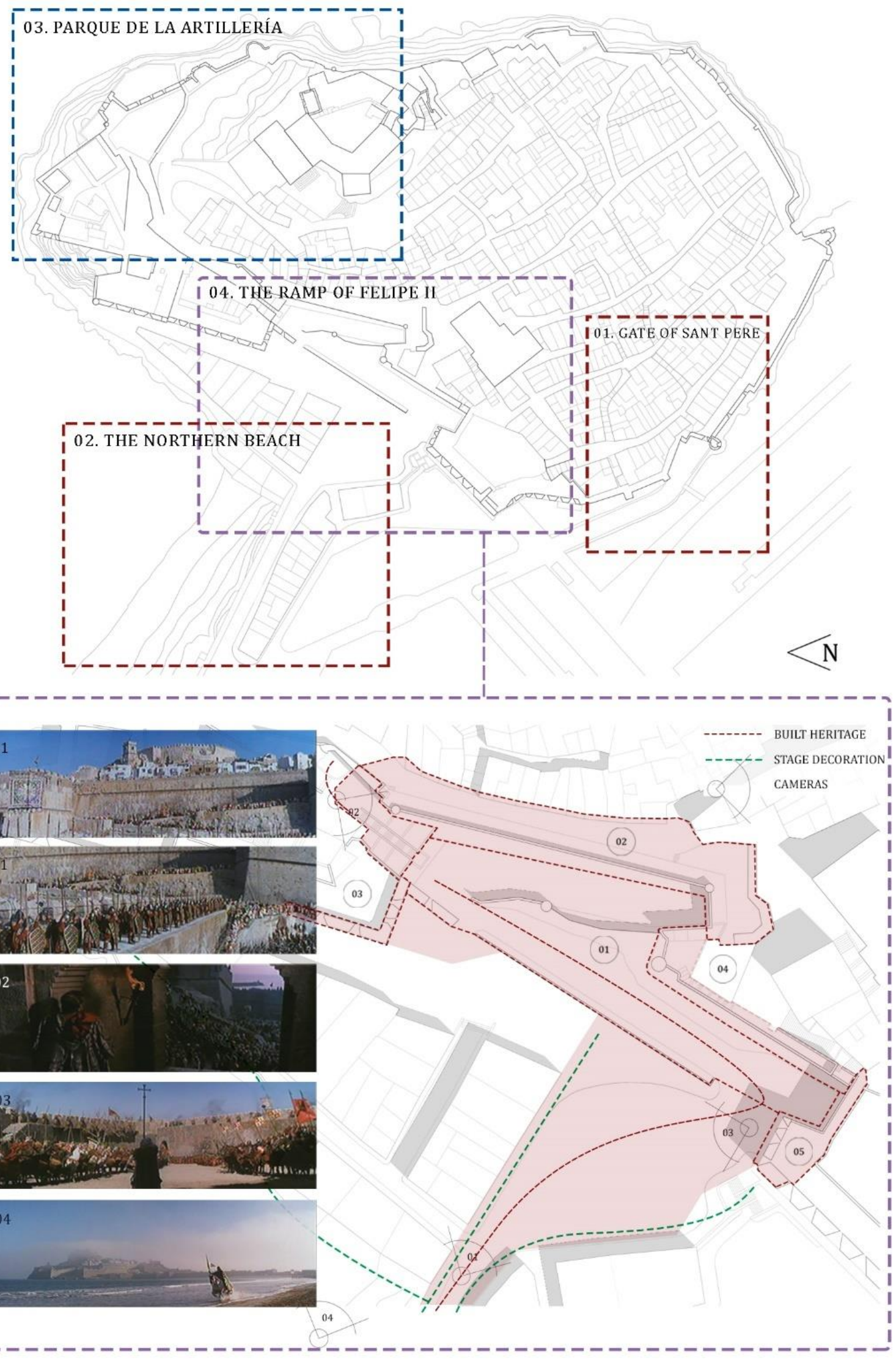

Figures 8. A Total of Four Film Sceneries: The Northern Beach and the Gate of Sant Pere, "El Cid" (1961) (red); "El Parque de la Artilleria", "Game of Thrones" (2011-2019) (blue); and the Ramp of Felipe II (in common) (Purple) and the study of its context, its heritage goods, its stage decoration and the an approximate location of the film cameras 


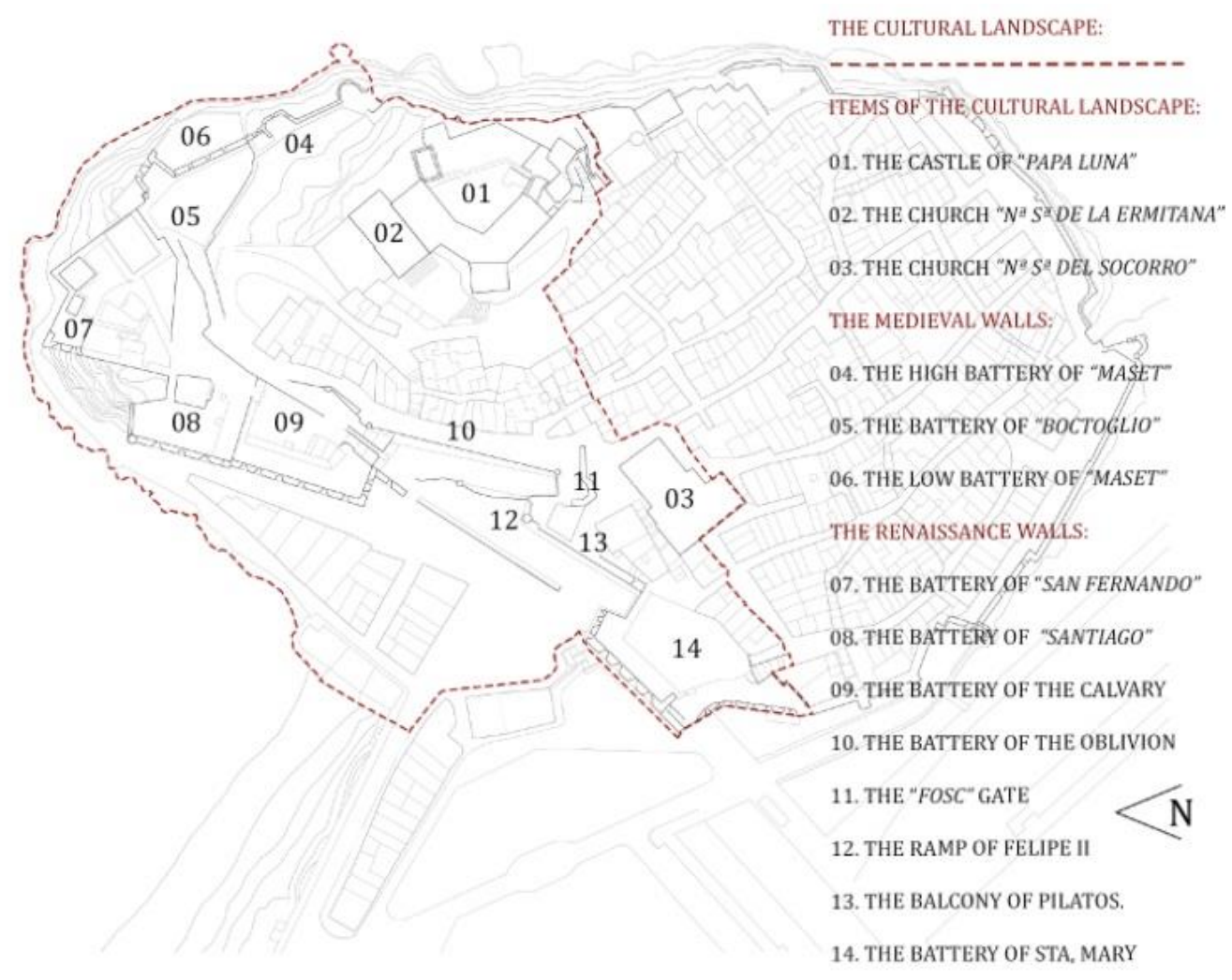

Figure 9. The Resulting Cultural Landscape: The Items of the Cultural Landscape (01, 02, 03); the Medieval Walls (04, 05, 06); the Renaissance Walls (07-14)

\subsection{The items and indicators of sustainable development}

After having defined the cultural landscapes, we need to ask ourselves about the concerns and worries referred to the type of tourist destination, so that we can appeal to the right indicators that will support them. To do that, we newly have to resort to the book "Indicators of Sustainable Development for Tourism Destinations" which contains a large number of worries regarding the different tourist destinations [13]. We will pick up some of these to be evaluated and take them as a base for elaborating a final list of questions, indicators and their sources of information more focused on cultural heritage, film sceneries and how the latter influences the former.

\subsubsection{Protecting and promoting the cultural value of a site}

The first question we need to make is related to the protection and the promotion of the cultural value of sites. And that is why we must resort to the "degree of conciliation" between traditional cultural heritage and film sceneries. The union of various film sceneries through built or landscape heritage can result in one or several cultural routes [20] we have entitled "Structures of Cultural Interest: Film Sceneries and Cultural Heritage" and that can help promote both the heritage goods and the film sceneries, without the latter overshadowing the former.

3.2.2 Tourism as a contributor to socio-cultural and environmental changes

The second point is referred to the existing balance between the traditional lifestyles of the host communities and the tourist requests. On the one hand, we need to analyze the state of preservation of the cultural goods of sites, their evolution and their perception alongside the already existing cultural routes or the new ones. Later, we must leave the paths and newly get a better perspective in the distance, so that we can visualize the entire cultural landscape, as we did in subsection 3.1.3. "Visual Perception of the Landscape". An accurate research involves both the study of local codes like Special Heritage Protection Plans, Special Reform Plans, Urban Planning Frameworks, etc. and the compilation of non-written testimonies like the citizens', since they are direct witnesses of their evolution and the communities', photographs, etc.

On the other hand, we must value the degree of satisfaction of the tourist demands, both the basic (infrastructures, accommodation, etc.) and the complementary (leisure, entertainment, etc.) ones throughout the cultural routes. The tourist presence in host communities has a great impact on both their day to day life and their future prospects. Firstly, the daily presence of tourists on the streets can contribute to destabilize both the intern image of the paths they are walking through and the entire image of the cultural landscape in the distance. Due to this, it is of great importance to design Tourism Promotion Plans and to carry out and consider customer satisfaction surveys in order to level both inhabitants and tourism presence. With regard to the future prospects, sometimes they are the host communities themselves that introduce some changes in the sites in order to attract and satisfy the tourist demands, such as the opening of new infrastructures, new hotels, etc. And most time, at the expense of the host communities and the cultural heritage.

\subsubsection{Culture and economical development of a site}

The final point is referred to culture and how this can provide economical benefits to the host communities. Firstly, we have to focus on the cultural activities provided by the tourist destinations (Tourist Offer) and later, on the audience reception before and after they became film sceneries (Use Intensity). 
Table 1. Structures of Cultural Interest: Cultural Heritage, Cinema and Cultural Tourism

\begin{tabular}{|c|c|c|c|c|c|}
\hline \multicolumn{2}{|c|}{ Films or TV. Series } & \multicolumn{4}{|c|}{ Cultural or Natural Heritage } \\
\hline El Cid (1961) & Game of Thrones (2011-2019) & Singular Buildings & Heritage Sites & Urban Spaces & Landscape Heritage \\
\hline $\begin{array}{l}\text { Complot } \\
(01: 17: 00)\end{array}$ & \multirow{2}{*}{$\begin{array}{l}\text { A walk through the streets of } \\
\text { Meeren }(6 x 01),(00: 29: 00)\end{array}$} & $\begin{array}{l}\text { Ramp of } \\
\text { Felipe II }\end{array}$ & \multirow{2}{*}{$\begin{array}{c}\text { Western } \\
\text { Renaissance Walls }\end{array}$} & $\begin{array}{l}\text { Ramp of } \\
\text { Felipe II }\end{array}$ & \multirow{2}{*}{$\begin{array}{l}\text { The Historic-Artistic } \\
\text { Centre of Peñíscola }\end{array}$} \\
\hline & & $\begin{array}{l}\text { Batery of Sta. María } \\
\text { Batery of La Fuente }\end{array}$ & & $\begin{array}{l}\text { Plaza Les } \\
\text { Caseres }\end{array}$ & \\
\hline
\end{tabular}

A couple of sequences of the films/ TV. series and the cultural/natural heritage that composes them: "El Cid" (1961) in red, "Game of Thrones (2011-2019) in blue, the cultural heritage in common in purple.

Table 2. Structures of Cultural Interest: Tourist Offer

\begin{tabular}{|c|c|c|c|c|c|}
\hline \multicolumn{2}{|c|}{ Tourist Offer } & \multicolumn{4}{|c|}{ Cultural or Natural Heritage } \\
\hline Historic Routes & Thematic Routes & Singular Buildings & Heritage Sites & Urban Spaces & $\begin{array}{l}\text { Landscape } \\
\text { Heritage }\end{array}$ \\
\hline \multirow{4}{*}{$\begin{array}{l}\text { Monumental } \\
\text { Route }\end{array}$} & & Gate of Sant Pere & $\begin{array}{c}\text { Southern } \\
\text { Renaissaince Walls }\end{array}$ & & \multirow{4}{*}{$\begin{array}{l}\text { The Historic- } \\
\text { Artistic Centre } \\
\text { of Peñíscola }\end{array}$} \\
\hline & & Gate of Fosc & \multirow{2}{*}{$\begin{array}{c}\text { Western } \\
\text { Renaissance Walls }\end{array}$} & & \\
\hline & & Gate of Sta. María & & Plaza Les Caseres & \\
\hline & & $\begin{array}{l}\text { Parochial Church of } N^{a} \\
S^{a} \text { del Socorro }\end{array}$ & $\begin{array}{l}\text { Calle Mayor } \\
\text { (Renaissance) }\end{array}$ & & \\
\hline
\end{tabular}

The "Monumental Route": an example of the cultural heritage of the site and its tourist offer.

Table 3. Basic Demands: The Uses of Buildings and Open Spaces

\begin{tabular}{|c|c|c|c|c|c|c|c|c|c|}
\hline \multicolumn{3}{|c|}{ Built Heritage } & \multicolumn{2}{|c|}{ The Uses of Buildings } & \multicolumn{3}{|c|}{ The Uses of Open Spaces } & \multicolumn{2}{|c|}{ Special Protection Plans for Heritage } \\
\hline Street & $\begin{array}{l}\mathrm{N}^{\circ} \text { (of } \\
\text { the } \\
\text { block) }\end{array}$ & $\begin{array}{l}\text { Height (of } \\
\text { Buildings) }\end{array}$ & $\begin{array}{l}\text { Ground } \\
\text { Floor }\end{array}$ & Others & $\begin{array}{l}\text { Pedestrian } \\
\text { Route }\end{array}$ & $\begin{array}{c}\text { Road } \\
\text { Network }\end{array}$ & $\begin{array}{c}\text { Car } \\
\text { Parking }\end{array}$ & Signature & $\begin{array}{l}\text { Degree of Protection/ } \\
\text { Intervention }\end{array}$ \\
\hline \multirow{6}{*}{$\begin{array}{c}\text { Plaza } \\
\text { Les } \\
\text { Caseres }\end{array}$} & & & & & \multirow{6}{*}{ Yes } & \multirow{6}{*}{ Yes } & \multirow{6}{*}{ Yes } & U113 & $\begin{array}{l}\text { Entire Protection } \\
\text { (Conservation) }\end{array}$ \\
\hline & 1 & 10.6 & Commerce & Housing & & & & \multirow{5}{*}{ E238 } & \multirow{5}{*}{$\begin{array}{l}\text { Conservation, Consolidation, } \\
\text { Restoration, Refurbishment }\end{array}$} \\
\hline & 2 & 10.6 & Commerce & Housing & & & & & \\
\hline & 3 & 10.6 & Commerce & Housing & & & & & \\
\hline & 4 & 10.6 & Commerce & Housing & & & & & \\
\hline & 5 & 10.6 & Commerce & Housing & & & & & \\
\hline
\end{tabular}

The Battery of Santa Maria: an example of the built heritage of the site, the elements that compose it (the Renaissance Walls, the inner buildings and the Plaza Les Caseres, the urban space they give shape to), their degree of protection and, consequently, the degree of intervention (according to the Special Protection Plans for Heritage of the Historic Centre of Peñíscola).

\subsection{The evaluation of the indicators of sustainable development}

Despite having reduce the number of questions to the three we have explained before and, consequently, the number of indicators, we aim to reduce them a lit bit more so that we can reach the final two synthetic indicators and evaluate them. These final indicators will be labeled as "Structures of Cultural Interest: Cultural Heritage, Cinema and Cultural Tourism" and "Basic Demands: The Uses of Buildings and Open Spaces”.

3.3.1 Structures of cultural interest: Cultural heritage, cinema and cultural tourism

The first of the synthetic indicators embraces the following: "Structures of Cultural Interest: Film Sceneries and Cultural Heritage", the "Visual Impact Management of the Cultural Landscape", referred to the state of preservation of cultural landscapes and the "Tourist Offer: Cultural Activities".

3.3.2 Basic demands: The uses of buildings and open spaces

The second synthetic indicator involves the already mentioned "The Satisfaction of the Basic and Complementary Demands alongside the Structures of Cultural Interest" and newly "The Visual Impact Management of the cultural
Landscape”, this time alluding to the excessive presence of tourists and the way they affect the host communities' lifestyles.

\subsubsection{Data collection: A series of tables and a plan}

All the information gathered from different sources of information (fieldwork, surveys, photographs, local, national or international regulations...) will be compiled in a series of tables and graphically represented in one single plan.

On the one hand, the written information will be organized in three different Tables (1, 2 and 3). Tables 1 and 2 will refer to the former indicator "Structures of cultural interest: Cultural heritage, cinema and cultural tourism". Table 1 will be divided into two sections: "Films or TV. Series" which contain the entire cinema productions chosen before and their respective film sequences and "Cultural or natural heritage", which is subdivided into four parts: "Singular buildings", "Heritage sites", "Urban spaces" and "Landscape heritage" (Table 1). Table 2 will be the same. However, the former section "Films or TV series" will be replaced with another one known as "Tourist offer", regarding the local cultural routes and will consist of two subsections: "Historic routes" and "Thematic routes" (e.g. Film routes, gastronomic routes...) [21] (Table 2). Table 3, however, will involve the latter indicator "Basic demands: the uses of buildings and open 
spaces". This table is organized in four sections: "Built heritage", which includes the name of the streets that are part of the structures of cultural interest, the numbers of the doorways and the height of the buildings; "The uses of the buildings" on every floor, "The uses of the urban spaces" (for pedestrians, road traffic, parking...) and "Special Protection Plans for Heritage (Table 3). All this information will help us understand the current state of conservation of the cultural landscape and its future prospects (depending on if it was protected or not and, in case it was protected, the degree of protection).

On the other hand, the whole cultural landscape, all the structures of cultural we have named above and all the elements they consist of (heritages goods, other tourist attractions, accommodations, catering and the paths that connect them all) will be graphically represented on the plan we have mentioned before.

3.3.4 The evaluation of the indicators of sustainable development for the Historic Centre of Peñíscola

To put into practice this methodology, we are newly appealing to the cultural landscape inside the Historic Centre of Peñíscola. To do that, we are starting with the first of the indicators of sustainable development: "Structures of cultural interest: Cultural Heritage, cinema and cultural tourism". With reference to the data sources, there is a total of four structures of cultural interest inside the Historic Centre of Peñíscola and three of them inside our cultural landscape: the "Monumental Route", which consists of a visit through all the emblematic historic gates alongside the walls of the city; the "Historic-Artistic Route" which shows us some examples of the built heritage for which the Historic Centre of Peñíscola was recognized as a Historic-Artistic Site; and the more recent "Historic Centre Route" which leads us to a walk through the history of the site [22]. As we will observe later, these three routes have many places, buildings, e.g. in common and they are all meant to promote and, consequently, to preserve the built heritage of the place, its meaning and its value.

However, the Historic Centre of Peñíscola is also famous for the many times that it has become film scenery for the shooting of films and TV series. And as we have said before, film (cultural) tourism is an invaluable aid for the protection of cultural heritage or to the loss of its true identity in favor of a new attractive tourist product which are film sceneries. For this reason and in spite of the numerous cultural routes offered by the host community, we are proposing a forth one, a structure of cultural interest that aims to link the four film sceneries from the Middle Age set movie "El Cid" [19] and the fictional, but also medieval "Game of thrones" [10] through the built heritage of the Historic Centre of Peñíscola. We shall call this new route the "Cultural Film Route".

All the film sceneries lie at the west face of the Old Town and their union results in a structure of cultural interest that starts outside the walled city (at the northern beach) and ends up at the top of the tombolo, in the Castle of Pope Luna, passing through some examples of the Renaissance military architecture (the batteries of the Oblivion, of the Calvary, of Santiago, e.g.), some singular buildings such as the castle or the Church "La Ermitaña" and the residential complex.

The terrain is sloping, which means that the residential complex is staggered and, consequently, the "Cultural Film
Route" is mainly intended for pedestrians. Motor vehicle use and park are limited to some points at the very beginning of the path like the Ramp of Felipe II and the Battery of Santa Ana. Thanks to this, people will have the chance of enjoying a route free of obstacles, from which they can achieve a better comprehension of both built and landscape heritage while they walk through the streets or they have a break in a local establishment.

All this information has been compiled in the tables we have mentioned before (Tables 1, 2, 3) and in a final plan (Figure $10)$.

\section{DISCUSSIONS AND RESULTS}

After having evaluated our study case, we have come to the following conclusions:

On the first hand, since it strives for the right balance between the traditional cultural heritage of sites and film sceneries, the proposed methodology has proved to be accurate for the evaluation of these kinds of tourist destinations. The degree of conciliation between built/ landscape heritage and film sceneries leads us to value and enjoy both of them separately without the latter overshadowing the former.

The degree of conciliation varies regarding the similarities and differences between traditional cultural heritage (REALITY) and the set of the cinema productions (FICTION). Referring to our study case, we have concluded that the degree of conciliation between its built/ landscape heritage and the four film sceneries is high, given the fact that both cinema productions are historical and that their film sceneries are located alongside the western Renaissance walls, which are highly protected according to the Special Protection Plan for Heritage of the city and in the northern beach from which we can admire the whole complex, declared a Historic-Artistic Site in 1972. Furthermore, the union of the four film sceneries through the built heritage results in a structure of cultural interest that entirely matches a stage of one of the cultural routes offered by the host community, the Historic Centre Route and has points in common with the rest, as we can observe in the following location plan (Figure 10). In short, the location of the film sceneries inside and in the surroundings of the Historic Centre of Peñíscola highlights the local built heritage of the site and, consequently, it is a good way to present it to the public.

However, we must take into account that historically, the film settings do not match the built heritage of Peñíscola since both of them are set in the Middle Age: in the film "El Cid" [19], the western Renaissance walls of the Old Town of Peñíscola converted themselves into walls of the city of Valencia in the $11^{\text {th }}$ century and in "Game of thrones" [10], the walls of a fictional but still medieval city of Meeren. In brief, although the location of the film sceneries is enough for promoting the local heritage, we must not misunderstand their meaning.

In spite of not being represented on the plan due to a large range of uncertainties and consequently, of indicators, the human factor must always be taken into account since this involves altering the host communities' lifestyle, their landscapes' image and, as a result, misrepresenting their true identity. 


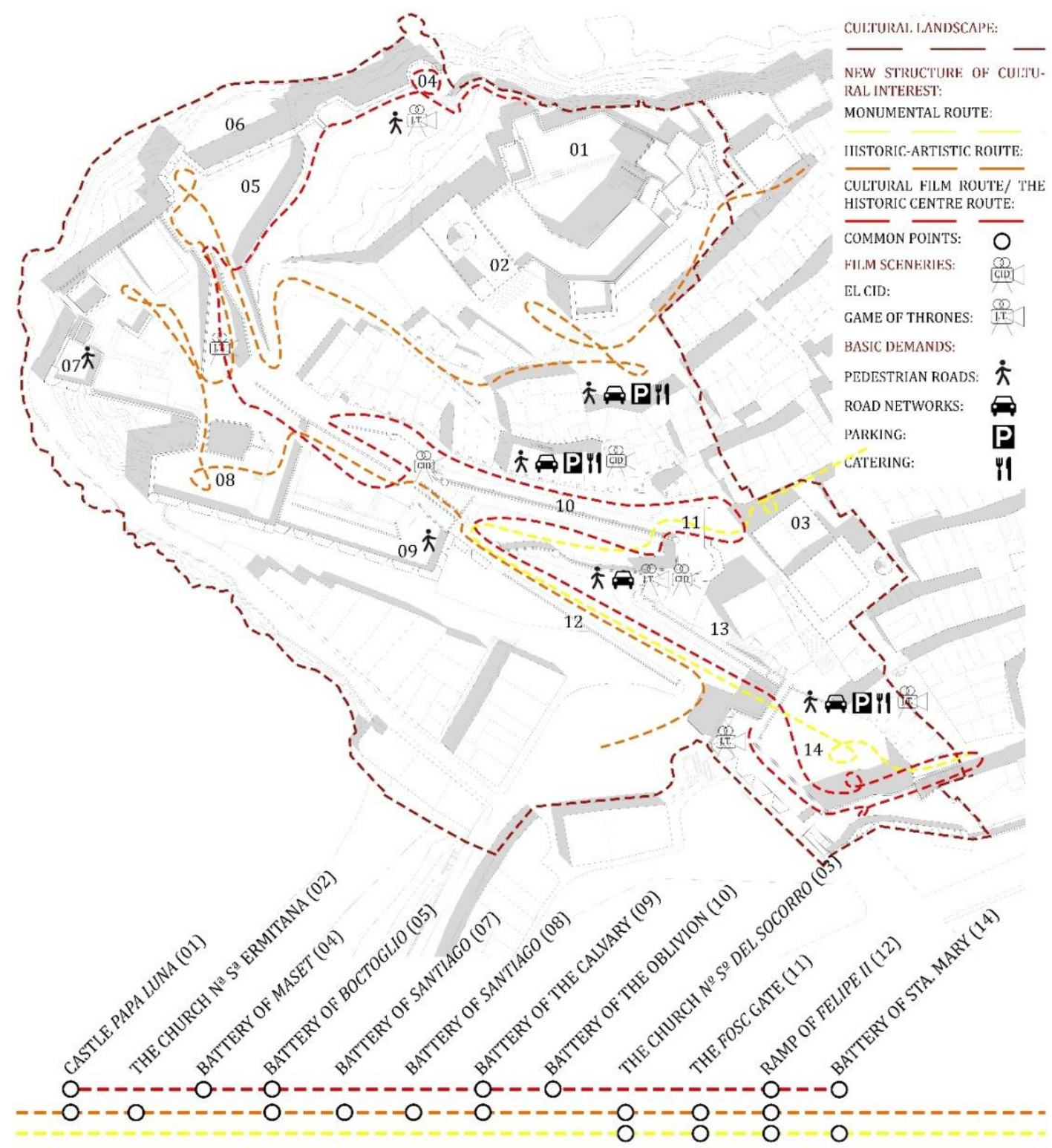

Figure 10. The Evaluation of Indicators of Sustainable Development: "Structures of Cultural Interest" and "Basic Demands"

On the second hand, this methodology should be applicable to other study cases so that we can evaluate and improve it. The Historic Centre of Peñíscola is been film scenery since the 1920 s, which means it is used to film tourism and that can be more prepared to receive a new mass of tourist attracted to this new tourist product. At first, we aim to focus on study cases with a considerable experience on film sceneries for two reasons: firstly, we pretend to evaluate their film career and how this has affected the host communities, their traditional lifestyles and their cultural heritage so that we can collect data for valuing their current degree of sustainability and their future prospects. Secondly, we want to take these study cases as a reference to collect further information for improving and perfecting the exposed methodology and, later, to put it into practice on study cases with a very brief film career and, consequently, which are not be ready for a new mass of tourist that can contribute to destabilize their traditional lifestyles.

Finally, all the information provided by the final indicators and these have to be checked and supplemented with others regularly, so that the data can remain updated and, as a result, we can ensure sustainable tourist destinations in the future.

\section{CONCLUSIONS}

Throughout the following methodology, we have concluded that the built/landscape heritage of the Historic Centre of Peñíscola and its film sceneries emphasize with each other, maintaining a proper balance between the welfare of the host community and tourist demands and, consequently, guaranteeing a high degree of sustainability. However, if we want to guarantee long-term sustainability of this and other sites, indicators must be regularly reviewed and, from time to time, renewed.

This methodology has only been applied on the current study case, which has helped us test and improve it. But there are many cases we haven't reached, but we aim to.

But most importantly, we must never forget that each case is unique and unrepeatable, in spite of applying the same methodology on all of them. Although they have some characteristics in common, they are all different and that is the way we should treat them, according to their singularities, where the main assets of each monument and site lie, not to the similarities. 


\section{REFERENCES}

[1] ICOMOS. (1976). Charter of Cultural Tourism, Seminar on Contemporary Tourism and Humanism. https://ipce.culturaydeporte.gob.es/dam/jcr:7bec19178752-4444-ab46-d7e0add3edad/1976-carta-turismocultural-bruselas.pdf, accessed on Jul. 17, 2020.

[2] Fernández Gracia, R. (2018). Patrimonio e Identidad (1). A Modo de Introducción. Diario de Navarra, pp. 84-85. https://www.academia.edu/37504772/_Patrimonio_e_id entidad_1_A_modo_de_introducci\%C3\%B3n_Diario_d e_Navarra_28_de_septiembre_de_2018_p\%C3\%A1gs_ 84_85, accessed on Aug. 21, 2020.

[3] Hmood, K., Jumaily, H., Melnik, V. (2018). Urban architectural heritage and sustainable tourism. In WIT Transactions on Ecology and the Environment, 227: 209220. http://dx.doi.org/10.2495/ST180201

[4] Parra López, E., Calero García, F. (2006). Gestión y Dirección de Empresas Turísticas. Mcgraw Hill Editorial.

[5] Rodríguez Campo, L., Fraiz Brea, J.A., González, E.A. (2014). El turismo cinematográfico como tipología emergente del turismo cultural. PASOS, Revista de Turismo y Patrimonio Cultural, 12(1): 159-171. https://doi.org/10.25145/j.pasos.2014.12.012

[6] Evans, M. (1997). Plugging into TV Tourism, Insights. 35-38.

[7] Amarilla, B., Conti, A. (2012). Built heritage and sustainable tourism: Conceptual, economic and social variables. Sustainable Development Policy and Urban Development - Tourism, Life Science, Management and Environment, 148-174. http://dx.doi.org/10.5772/28684

[8] Columbus, C., Cuarón, A., Newell, M., Yates, D. (20012011). Harry Potter (DVD), United Kingdom-U.S.A., Warner Bros., Heyday Films, 1492 Pictures.

[9] Jackson, P. (2001-2003). The Lord of the Rings (DVD). New Zealand - U.S.A.; Wingnut Films.

[10] Benioff, D., Weiss, D.B. (2011-2019). Game of Thrones (DVD). U.S.A. Home Box Office (HBO), Management 360.

[11] Allen, W. (2020). Rifkin's Festival (upcoming), U.S.A. Spain; Gravier Productions, Mediapro, Wildside.

[12] UNED, UNWTO. (2005). Making Tourism More Sustainable - A Guide for Policy Makers. UNWTO, 1112. https://doi.org/10.18111/9789284408214

[13] UNTWO. (2005). Indicators of Sustainable
Development for Tourism Destinations - A Guidebook (Spanish Version). UNWTO, Madrid. https://doi.org/10.18111/9789284408382

[14] Blancas Peral, F.J., González Lozano, M., Guerrero Casas, F.M., Lozano Oyola, M. (2010). Indicadores sintéticos de turismo sostenible: una aplicación para los destinos turísticos en Andalucía. Revista electrónica de Comunicaciones y Trabajos de ASEPUMA (ed.), 11: 85118. http://www.revistarecta.com/n11/recta_11_09.pdf, accessed on Jul. 20, 2020.

[15] Caraballo Perichi, C. (2009). Volviendo a los indicadores. La cuantificación de los criterios patrimoniales ¿Un objetivo alcanzable? Crónica de un ejercicio colectivo en el análisis de casos mexicanos de la Lista del patrimonio Mundial. El paisaje histórico urbano en las ciudades históricas patrimonio mundial: indicadores para su conservación y gestión. Instituto Andaluz del Patrimonio Histórico (ed.), 1: 58-69. https://www.juntadeandalucia.es/organismos/culturaypa trimoniohistorico/iaph/servicios/publicaciones/detalle/7 8724.html, accessed on Aug. 21, 2020.

[16] UNESCO. (1972). Convention for the Protection of the World Cultural and Natural Heritage. France. https://unesdoc.unesco.org/ark:/48223/pf0000002091, accessed on Aug. 22, 2020.

[17] UNESCO. (1992). Expert Group on Cultural Landscapes. France. http://whc.unesco.org/archive/pierre92.htm, accessed on Aug. 15, 2020.

[18] Berlanga, L.G. (1956). Calabuch (DVD). España-Italia, Águila Films, Films Costelazione.

[19] Mann, A. (1961). El Cid (DVD). Estados Unidos e Italia, Dear Film Produzione, Samuel Bronston Productions.

[20] ICOMOS. (2008). Chapter on Cultural Routes. ICOMOS, Canadá. https://www.icomos.org/images/DOCUMENTS/Charter s/culturalroutes_sp.pdf, accessed on Aug. 21, 2020.

[21] Hernández Ramírez, J. (2011). Los caminos del patrimonio. Rutas turísticas e itinerarios culturales. PASOS. Revista de Turismo y Patrimonio Cultural, 9(2): 225-236. https://doi.org/10.25145/j.pasos.2011.09.021

[22] Tourism in Peñíscola. http://www.peniscola.es/peniscola/cultura-ypatrimonio/rutas-culturales/\#.Xe6Mcm5FzIV, accessed on Nov. 18, 2019. 